(Uniwersytet Warszawski, e-mail: aneta.syta@wp.pl)

ORCID: 0000-0001-7487-4083

\title{
ZABURZENIA SPRAWNOŚCI JĘZYKOWYCH I KOMUNIKACYJNYCH U CHORYCH PO UDARZE PRAWEJ PÓEKULI MÓZGU. OPISY PRZYPADKÓW
}

\section{WPROWADZENIE}

Prawa półkula mózgu przez wieki uznawana była za mało istotna w regulacji zachowań językowych. Jej rolę wiązano jedynie $z$ funkcjami wzrokowo-przestrzennymi. Jeżeli chodzi o regulowanie czynności językowych, udział prawej półkuli mózgu zawężano do zautomatyzowanych wyrażeń i stereotypowych zwrotów dotyczacych liczenia, śpiewania, recytowania wierszy itp. Dopiero dzięki badaniom przeprowadzonym w ostatnich latach wykazano istotna rolę prawej półkuli mózgu w przebiegu procesów językowych. Badania kliniczne, w szczególności $z$ wykorzystaniem dynamicznie rozwijających się w drugiej połowie XX wieku technik neuroobrazowych, pozwoliły na wykazanie istotnej roli prawej półkuli mózgu w organizowaniu danych werbalnych i niewerbalnych [Panasiuk 2015].

Niezwykle istotnych informacji na temat znaczenia prawej półkuli mózgu dla języka dostarczyły badania osób po hemisferektomii, ${ }^{1}$ którym usunięto lewą półkulę mózgu. Po zabiegu okazało się, że część funkcji językowych nie została utracona przez pacjentów. Ponadto u niektórych po pewnym czasie można było zauważyć poprawę dotycząca rozumienia komunikatów oraz ekspresji językowej [Walsh 2008].

Wyżej opisane zaburzenia dotyczace języka oraz komunikacji, które są wynikiem uszkodzenia prawej półkuli mózgu, nazywa się pragnozja. Do tej pory nie znalazła ona miejsca w międzynarodowych klasyfikacjach chorób, natomiast w logopedii jest osobna jednostką patologii mowy.

Pragnozja (nieafatyczne zaburzenia mowy) - obejmuje nabyte na skutek ogniskowych uszkodzeń podległej (zwykle prawej) półkuli mózgu, zaburzenia zachowań językowych i komunikacyjnych. Podległa półkula mózgu odpowiada za pewne elementarne zdolności językowe, ale przede wszystkim jest związana $z$ analizą pragmatycznych aspektów wypowiedzi (...) [Panasiuk 2008].

1 Usunięcie jednej półkuli mózgu (zabieg polega na przecięciu spoidła wielkiego mózgu). 


\section{OPIS DEFICYTÓW JĘYKOWYCH I KOMUNIKACYJNYCH W SYTUACJI USZKODZENIA PRAWEJ PÓEKULI MÓZGU. OPISY PRZYPADKÓW PACJENTÓW Z PRAGNOZJĄ}

Moja motywacją do badań była chęć oceny funkcji językowych u osób $z$ uszkodzeniem prawej półkuli mózgu, opisanie ich trudności w codziennej komunikacji oraz sprawdzenie konkretnych kompetencji językowych i komunikacyjnych na podstawie wybranych do tego prób.

Poniżej przedstawione zadania pochodzą $z$ :

1. autorskiego narzędzia do badania realizacji i percepcji prozodii emocjonalnej i lingwistycznej; ${ }^{2}$

2. zadań do oceny funkcji językowych chorych z pragnozją, które opracowałam samodzielnie i które oparte zostały na dostępnych w literaturze próbach badań specjalistów zajmujących się tym problemem.

Niżej przedstawione zostało sześć przykładów pacjentów, u których uszkodzeniu uległa prawa półkula mózgu. Najczęściej przyczyną uszkodzenia był udar niedokrwienny tej półkuli lub wypadek komunikacyjny. Wszyscy niżej opisani pacjenci poddani zostali diagnozie neurologicznej, psychiatrycznej oraz logopedycznej. Na podstawie tej ostatniej u każdego $z$ nich rozpoznano pragnozję. ${ }^{3}$ Poniższe przykłady maja na celu opisanie i dokładne scharakteryzowanie dysfunkcji językowych i komunikacyjnych osób z pragnozją.

Badania odbywały się w Górnośląskim Centrum Rehabilitacji im. gen. Jerzego Ziętka "REPTY” w Tarnowskich Górach i trwały od 1 do 21 sierpnia $2018 \mathrm{r}$.

\section{METAFORA}

Podczas badań powadzonych w ostatnich latach wielu naukowców podważa założenia o niejęzykowym charakterze prawej półkuli mózgu. Badania wskazuja, że osoby z uszkodzona prawa półkulą mózgu mają trudności w rozumieniu dowcipów sytuacyjnych oraz złożonych opowiadań [Łojek 2007; Code 1987].

W przedstawionych im opowiadaniach nie potrafia zaobserwować zawartych tam nieprawidłowości oraz próbuja znaleźć dla nich logiczne wytłumaczenie [Kaczmarek 1995]. W sposób dosłowny rozumieją znaczenia metaforyczne, sarkazm, ironię, przez co często mają problemy między innymi $z$ rozumieniem dłuższych wypowiedzi, ale też bardzo trudno przychodzi im łączenie części wypowiedzi w całość [Osiejuk 1994].

2 Narzędzie zostało opracowane na potrzeby własnej dysertacji doktorskiej dotyczacej zaburzeń prozodii mowy u osób z pragnozją.

3 Diagnozę wykonali logopedzi pracujący w GCR „Repty”, na podstawie Baterii do oceny funkcji językowych prawej półkuli mózgu Karen L. Bryan [2007]. 


\section{Przykład 1. Pacjentka Z.K., 51 lat \\ Wykształcenie: podstawowe}

Rozpoznanie kliniczne: Stan po udarze niedokrwiennym prawej półkuli mózgu, niedowład połowiczny lewostronny, zaburzenia funkcji poznawczych. Matka pacjentki miała udar krwotoczny mózgu (tętniak).

Pacjentka miała wysłuchać zdań czytanych przez lektora i odpowiedzieć na zadane przez badającego pytania. ${ }^{4}$

1) Mężczyzna musiał brać nogi za pas, ponieważ gonit go rozdrażniony hipopotam. Ich jabtkiem niezgody było jedzenie, które człowiek próbował zabrać zwierzęciu.

- Co musiał zrobić mężczyzna?

- Co było przyczyną?

2) Agata była molem książkowym, więc na urodziny dostała encyklopedie.

- Co lubiła robić Agata?

2) Jedna $z$ pacjentek $w$ poczekalni uważała się za pępek świata $i$ postanowiła wejść do gabinetu bez kolejki. Pozostali pacjenci siedzieli jak mysz pod miotta, więc kobieta dopięta swego.

- Co myślała o sobie opisana kobieta?

- Jak zareagowali pozostali pacjenci?

Pacjentka miała problem $z$ odpowiedzią na większość pytań, gromki śmiech wywołało u niej wyrażenie metaforyczne peppek świata oraz brać nogi za pas, co świadczy o całkowitym niezrozumieniu wyrażeń metaforycznych.

Pacjenci cierpiący na pragnozję dosłownie interpretuja język metaforyczny, maja problem $z$ wyborem, które znaczenie metafory (dosłowne czy przenośne) jest odpowiednie w odniesieniu do danego kontekstu [Winner i Gardner 1997; Brownell 2000; Jodzio 2001].

Uszkodzenie prawej półkuli mózgu powoduje również problemy $z$ wydobywaniem $z$ wypowiedzi innych ukrytych znaczeń [Brownell 2000].

4 Opracowanie własne: zadania oparte na badaniach E. Winner i H. Gardner [1977]. 


\section{Przykład 2. Pacjentka A.P., 54 lata \\ Wykształcenie: wyższe}

Rozpoznanie kliniczne: Udar niedokrwienny prawej półkuli mózgu. Pięć lat wcześniej uszkodzenie prawej półkuli mózgu na skutek wypadku komunikacyjnego. Cechy obrzęku prawej półkuli w zakresie płata skroniowo-ciemieniowego - wygładzenie rowków i bruzd mózgowych.

Pacjentka została poproszona o rozpoznanie i opisanie jednego $z$ najsłynniejszych surrealistycznych obrazów Salvadora Dalego - Trwałość pamięci.

B: Co Pani widzi na tym obrazie?

P: Zegar spalony, pod wpływem słońca. A! Kilka zegarów.

B: Czy widzi Pani coś dziwnego w tym obrazie?

P: Nie, właściwie to sa duże liście, pomyliłam się.

B: Dlaczego uważa Pani, że sa to duże liście, a nie zegary, tak jak wcześniej Pani powiedziała?

P: Ja od poczattku uważałam, że to są duże liście, bo przecież jest drzewo, jakiś krajobraz, ale zmyliły mnie wskazówki od zegara.

Pacjentka nie potrafiła dostrzec istoty i znaczenia obrazu. Pomimo prawidłowego wzroku opisała zegary na obrazie jako liście, sugerujac się krajobrazem widniejaccym na obrazie.

\section{DYSKURS}

Pacjenci cierpiący na pragnozję w swych wypowiedziach bardzo często skupiają uwage na szczegółach, które sa nieistotne, często odbiegają od tematu, nierzadko wplataja w rozmowę wiele uwag osobistych [Osiejuk 1994].

\section{Przykład 3. Pacjent A.Z., 57 lat}

Wykształcenie: wyższe

Rozpoznanie kliniczne: Stan po udarze niedokrwiennym rdzenia przedłużonego leczonym trombolitycznie, następstwa zawału mózgu (zaburzenia równowagi, niedowład lewostronny czterokończynowy).

Rozmowa $z$ pacjentem, której tematem miały być jego ulubione filmy:

B: Proszę opowiedzieć mi o tym, jakie filmy lubi Pan najbardziej oglądać?

P: Proszę Pani, ja nie oglądam telewizji, mam dość tego co się dzieje, nie będę oglądał telewizji. Mogę Pani powiedzieć, że kocham czytać, kocham poezję oraz literaturę i powiem Pani, że jestem poeta.

B: Wspaniale! Proszę opowiedzieć mi coś więcej o Pana twórczości, z chęcia posłucham.

P: Jestem poeta, i mam kochankę..., bo wie Pani, że każdy poeta musi mieć swoją kochankę.

B: To ciekawe... 
P: To biblioteka we Wrocławiu, wspaniała, pachnaca biblioteka. Powiem Pani, że poznałem tam moja żonę, ale miałem ciężkie życie. Dałem córce na imię Elżbieta, to piękne imię, ale później mówiłem na nią Anna. Ostatnio spacerowałem, obserwując gwiazdy i ciesząc się $z$ tego, jak piękny jest świat, jak wiele już osiagnąłem.

B: Widzę, jak duże postępy robi Pan w związku z Pana rehabilitacja, jednak może opowie mi Pan coś więcej o swojej poezji?

P: Piszę o tym, co mnie otacza, o sytuacji politycznej, o Polsce, którą kocham. Tak. Napoleon to był gość. Prawdziwy strateg na białym koniu. Może kiedyś ja przyjadę po Panią na białym koniu.

B: Niewykluczone. Zaczał Pan wcześniej opowiadać o tym, jak poznał swoja żonę, może opowie mi Pan o tym coś więcej.

P: Poznałem moją żonę i bardzo się cieszę, jest piękna i mądra. Wcześniej znałem same kur**.

Pacjent stawał się coraz bardziej natarczywy i rozhamowany, mimo kilkukrotnego zwrócenia uwagi na niecenzuralne słowa i próby naprowadzenia pacjenta na tor rozmowy nie udało się zdobyć informacji, o które proszono. Pacjent w pewnym momencie zaczął prowadzić monolog, nie zwracając uwagi na swojego rozmówcę. Przytoczony przykład niewątpliwie świadczy o poważnych zaburzeniach w dyskursie.

Chorzy często wprowadzają do konwersacji komentarze, które sa nieadekwatne do tematu rozmowy. Pojawia się również mnóstwo mało istotnych uwag oraz dygresji. Pacjenci $z$ deficytami prawej półkuli przemycaja do rozmowy nowe informacje, które sa niespójne $z$ głównym tematem rozmowy. Maja skłonność do koloryzowania swoich opowieści, a podczas dialogu nie chcą dopuścić rozmówcy do głosu lub wręcz przeciwnie - nie podtrzymuja rozmowy [Senderecka 2007; Rożek, Larysz 2014; Tompkins 1995].

\section{ZDOLNOŚCI PRAGMATYCZNE, HUMOR}

W zakresie sprawności komunikacyjnych zaburzenia ujawniaja się w realizacji językowych reguł społecznych, pragmatycznych i sytuacyjnych jako brak zdolności formułowania komunikatów, które byłyby stosowne do sytuacji, rozmówcy i pragmatycznych funkcji przekazu [Ross 1981].

\section{Przykład 4. Pacjent B.P., 29 lat \\ Wykształcenie: średnie}

Rozpoznanie kliniczne: Stan po udarze niedokrwiennym prawej półkuli mózgu, następstwa zawału mózgu (niedowład połowiczny lewostronny, ustępujaccy). W zakręcie przedśrodkowym prawego płata czołowego uwidoczniony niewielki udar niedokrwienny. Dwa lata wcześniej - udar nie- 
dokrwienny prawej półkuli mózgu, miesiąc później - stan po stentowaniu tętniaka.

Zadanie polegało na realizacji językowych reguł sytuacyjnych, ${ }^{5}$ pacjent miał za zadanie opisać to, jak zachowałby się w przedstawionej mu sytuacji.

Polecenie: Proszę odegrać razem ze mna scenkę: wyobraźmy sobie, że spotykamy się na pogrzebie żony naszego wspólnego znajomego. Co mi Pan / Pani powie?

P: No cóż... ciężka sprawa. Co by tu powiedzieć...(śmiech).

B: Dlaczego Pan się śmieje?

P: Skoro to mój znajomy, to bym mu powiedział: I za życia, i za śmierci, pozytywnie...(śmiech), niech Pani sama dokończy!

Powyższy przykład dobitnie pokazuje, że pacjent miał problem $z$ wyczuciem kontekstu i zachowaniem się odpowiednio do zaistniałej sytuacji.

Deficyty w zakresie pragmatyki objawiają się zaburzeniami prozodii, dyskursu, wyczucia kontekstu. Uniemożliwiają także rozumienie metafor oraz żartów [Łojek 2007; Patalong-Ogiewa, Lewicka 2013; Puchalska, MacQueen 2002].

Niewłaściwe poczucie humoru to kolejny deficyt, który charakteryzuje osoby $z$ uszkodzeniem prawopółkulowym. Poza opowiadaniem niesmacznych dowcipów pacjenci mają wiele trudności w odbiorze żartów wypowiadanych przez inne osoby [Brownell 2000; Jodzio 2001].

\section{PROCESY EMOCJONALNE, PROZODIA MOWY}

Mianem prozodii można określić „ogół brzmieniowych właściwości języka charakteryzujących sylaby lub ciagi sylab i wyrazów w toku wypowiedzi" [Dubisz 2004].

G. Monrad-Krohn [1947] jako pierwszy opisał zaburzenia prozodii i określił ją jako „melodię języka”, która obejmuje takie składniki mowy jak: akcent, intonacja, głośność, rytm, tempo mowy. Prozodię można podzielić na emocjonalna (afektywną) i lingwistyczną [Gurański i wsp. 2008].

Prozodia emocjonalna jest istotnym zjawiskiem w komunikacji językowej. Będac jej integralnym składnikiem, ma wpływ na proces przyswajania języka oraz sprawnego komunikowania się $z$ otoczeniem [Rymarczyk 1999]. Na gruncie dotychczasowych badań przyjmuje się, że prozodia emocjonalna ma bezpośredni związek $z$ uczuciami nadawcy komunikatu, który ma możliwość modyfikowania znaczenia swoich wypowiedzi poprzez nadawanie im zabarwienia ironicznego czy sarkastycznego [Wysocka 2012].

5 Opracowanie własne. 
Odbiór oraz rozumienie stanów emocjonalnych, a także przeżyć innych osób, to percepcja emocji, która

dokonywana jest w znacznej mierze poprzez odczytywanie niewerbalnych sygnałów wyrażanych w gestach, mimice (interpretacja wyrazu twarzy), a także w samej wypowiedzi (wyczucie brzmienia, intonacji mowy, czyli prozodii emocjonalnej). Ekspresja emocji, czyli wyrażanie stanów emocjonalnych, odbywa się w znacznej mierze poprzez mimikę oraz prozodię emocjonalną (odpowiednią intonację głosu) [Lewicka, Patalong-Ogiewa 2013].

\section{Przykład 5. Pacjent K.D., 42 lata \\ Wykształcenie: średnie}

Rozpoznanie kliniczne: Pacjent przyjęty ponownie do oddziału neurologii z powodu nasilenia niedowładu kończyn lewych po śnie nocnym. W wywiadzie: stan po udarze niedokrwiennym prawej półkuli mózgu, niedrożność RICA, nadciśnienie tętnicze, plegia kończyn lewych. Hipodensyjny nieregularny obszar obejmujący tylną część płata czołowego i dolną część płata ciemieniowego.

Pacjent został poproszony o wczucie się w rolę osoby wzywającej karetkę i przeczytanie kwestii oznaczonych litera A, natomiast badajacy miał za zadanie przeczytanie kwestii oznaczonych litera B. Zadanie miało na celu zbadania tego, jak realizują prozodię emocjonalną pacjenci z pragnozją.

A: Halo! Dzień dobry! Chciałem wezwać karetkę! Mój kolega nagle zasłabł!

B: Dzień dobry, proszę podać miejsce zdarzenia.

A: On spadł ze schodów, krwawi mu głowa!

B: Proszę się uspokoić. Niech Pan poda mi adres, na który mamy przyjechać oraz swoje imię i nazwisko. ${ }^{6}$

A: Polna 12, Jan Kowalski. Niech Państwo mi pomoga, bardzo się o niego boję!

B: Proszę zachować spokój, już jedziemy!

Zdania zostały przeczytane przez pacjenta bez emocji, w sposób monotonny. Dzięki prozodii emocjonalnej, a dokładniej na podstawie intonacji wypowiedzi, można odgadnąć uczucia nadawcy komunikatu [Osiejuk 1994; Rymarczyk 1999]. Prozodia emocjonalna była w tym przypadku zaburzona.

${ }^{6}$ Próba $\mathrm{z}$ autorskiego narzędzia do Badania realizacji i percepcji prozodii emocjonalnej i lingwistycznej. 
Kolejne zadanie polegało na tym, że lektor czytał pierwszą część zdania, natomiast pacjent miał za zadanie przeczytanie wyróżnionego zdania odpowiednim według siebie tonem głosu i wedle emocji, którą czuje. ${ }^{7}$ 1) Robert nie mógł uwierzyć $w$ to, że znowu nie zdał egzaminu, zszokowany zapytat wykładowcę: „Jak to możliwe?”

2) Mama po raz kolejny sprzatała papierki po cukierkach, które jej syn wetknat za kanape, zdenerwowana powiedziała do niego „To juz ostatni raz, kiedy po tobie sprzatam!"

Spodziewaną odpowiedzia było przeczytanie pogrubionych zdań $\mathrm{w}$ pierwszym przykładzie ze zdziwieniem, a w drugim zdaniu ze złościa. ${ }^{8}$ Podobnie jak w poprzednim zadaniu pacjent pomimo sterowanych zdań nie przeczytał ich zgodnie $z$ przewidywana emocja.

Nieodpowiednia interpretacja stanów emocjonalnych innych osób może wynikać $z$ tego, że w procesie przetwarzania emocji występuja zakłócenia. Często wynikiem takiego stanu rzeczy jest niewłaściwe zachowanie się wśród ludzi [Code 1987; Pell, Baum 1997].

Chorzy maja problem $z$ identyfikacją emocji w mimice twarzy innych osób oraz $z$ odpowiednim przypisywaniem właściwej ekspresji twarzy do poszczególnych stanów emocjonalnych [Bowers i wsp. 1991; Heilman i wsp. 2000; Kucharska-Pietura, Klimkowski 2002; Kucharska-Pietura i wsp. 2003].

Zadaniem na realizacje prozodii lingwistycznej było intonowanie głosu lektora (zdanie oznajmujace, pytające oraz rozkazujące). ${ }^{9}$
1) Przestań śpiewać.
2) Przynieść płaszcz!
3) Jedziemy na narty?

Pacjent dość dobrze poradził sobie $z$ przeczytaniem powyższych zdań, natomiast dużo większą trudność miał z percepcją prozodii lingwistycznej.

Po odtworzeniu tych samych zdań pacjent miał za zadanie zaznaczyć na karcie odpowiedzi odpowiedni znak interpunkcyjny, który jego zdaniem odpowiadał usłyszanemu zdaniu. Najwięcej trudności sprawiło mu rozróżnienie zdania oznajmującego od zdania rozkazującego.

7 Próba $z$ autorskiego narzędzia do Badania realizacji $i$ percepcji prozodii emocjonalnej $i$ lingwistycznej - skonstruowana na podstawie badań przeprowadzonych przez Dirka Traunera wraz z jego zespołem w 1996 roku [Trauner i in. 1996].

8 Złość i smutek - dwie spośród pięciu emocji wg Paula Ekmana [Ekman 1993], który wyróżnił pojęcia emocji podstawowych: złość, strach, wstręt, smutek i radość. Oryginalnie podane przez autora nazwy angielskie to: anger, fear, disgust, sadness, enjoyment.

9 Próba $z$ autorskiego narzędzia do Badania realizacji i percepcji prozodii emocjonalnej i lingwistycznej. 


\section{MECHANIZMY LEKSYKALNE I SEMANTYCZNE}

Mechanizmy leksykalno-semantyczne daja wiedzę na temat słów i obejmuja takie składniki języka jak: fonetyka, gramatyka i semantyka. Pacjenci $z$ dysfunkcjami prawej półkuli maja trudności m.in. w rozumieniu antonimów. Wiele badań wskazuje na to, że chorzy lepiej radzili sobie, jeśli musieli podać wyraz synonimiczny do słowa, które miało powszechnie przyjęte przeciwstawienie, niż do słów, których antonimy były nietypowe. Dodatkowa obserwacją było to, że chorzy dobierali słowa o znaczeniu zbliżonym, a nie przeciwstawnym [Osiejuk 1994].

Pacjenci z pragnozja mają również problemy w rozumieniu oraz definiowaniu poszczególnych słów, nawet jeśli są zauważalne na etapie formułowania definicji, jak i w wyborze słowa spośród innych [Code 1987; Herzyk 2008]. Problemy pojawiaja się również na poziomie fluencji werbalnej, chorzy mają spore trudności w wyszukaniu jak największej liczby słów według podanego odgórnie kryterium [Jodzio 2001; Łojek 2007].

U pacjentów $z$ uszkodzona prawą półkulą mózgu można zaobserwować zatem mniejszą zdolność ustalania semantycznych związków między słowami niż u osób zdrowych [Żulewska 2012].

\section{Przykład 6. Pacjent O.M., 35 lat \\ Wykształcenie: średnie}

Rozpoznanie kliniczne: Udar krwotoczny prawej półkuli mózgu. Nadciśnienie tętnicze. Nasilenie niedowładu lewostronnego. W przeszłości stan po udarze krwotocznym lewej półkuli mózgu.

Pacjent został poproszony o: ${ }^{10}$

- definiowanie nazw stanów emocjonalnych np. radość, smutek, duma, znudzenie;

- definiowanie nazw rzeczy i zjawisk konkretnych np. poduszka, miska, kredka, rysunek.

Kolejnym zadaniem, które miał wykonać pacjent, było podanie antonimów poniższych wyrazów:

- szybko, ciemno, zimno, długi, madry, ładny, dzień, smutek, nagroda oraz wskazanie spośród poniższych słów wyrazów tych, które są synonimami słowa obraz:

- malowidło, oprawa, wizerunek, ozdoba, zdjęcie, malunek, portret, podobizna, krzyk.

Zadanie dotyczace polisemii polegało na tym, aby pacjent wyjaśnił, jaka jest różnica między zaznaczonymi wyrazami.

- Ucze sie języka hiszpańskiego.

Maciek ugryzł się $w$ język.

10 Opracowanie własne. 
- Wyjeżdżamy z miasta o pótnocy.

Pojedziemy na pótnoc.

Na poziomie definiowania słów u pacjenta pojawiły się duże deficyty $\mathrm{w}$ nazywaniu oraz ograniczona fluencja słowna. $Z$ kolei zadanie dotyczace antonimów wypadło stosunkowo dobrze, pacjent podał słowa przeciwstawne do 7 wyrazów. Zadanie, które dotyczyło wskazania synonimów wypadło nieco gorzej - pacjent wskazał tylko 3 poprawne wyrazy bliskoznaczne, natomiast najgorzej wypadło zadanie dotyczące polisemów. Chory nie był w stanie rozpoznać znaczenia polisemów w podanym kontekście.

\section{PODSUMOWANIE}

Pacjenci cierpiący na deficyty językowe i komunikacyjne na skutek uszkodzenia prawej półkuli mózgu stanowia grupę reprezentująca jednostkowy profil zaburzeń. Pacjent $z$ uszkodzeniem prawopółkulowym powinien być otoczony opieka i szczególną czujnością ze strony logopedy, ponieważ jego deficyty językowe, emocjonalne oraz społeczne wymagaja zindywidualizowanego planu terapeutycznego, którego głównym celem powinna być odbudowa funkcji językowych, polegająca m.in. na ćwiczeniach dotyczacych usprawniania prozodii mowy, ale równieź ćwiczenia dotyczace realizacji reguł społecznych, pragmatycznych oraz sytuacyjnych [Panasiuk 2008].

Ponadto pojawia się pilna potrzeba dalszych badań nad deficytami językowymi i komunikacyjnymi u pacjentów $z$ pragnozją oraz zwrócenia uwagi na to, że nie tylko lewa, ale i prawa półkula mózgu odpowiada za wiele funkcji językowych.

\section{Bibliografia}

D. Bowers, H. Coslett, R. Bauer, L. Speedie, K. Heilman, 1987, Comprehension of emotional prosody following unilateral hemispheric lesions: processing defect versus distraction defect, „Neuropsychologia” 25, s. 317-328.

H. Brownell, 2000, Right hemisphere contributions to understanding lexical connotation and metaphor [w:] Y. Grodzinsky, L.P. Shapiro, D. Swinney (red.), Language and the Brain: Representation and Processing,, San Diego, s. 185-201.

C. Code, 1987, Language, aphasia, and the right hemisphere, Chichester.

S. Dubisz (red. nauk.), 2004, Uniwersalny słownik jezzyka polskiego, Warszawa.

P. Ekman, 1993, Facial expression and emotion „American Psychologist” 48(4), s. 384-392.

K. Gurański, R. Słotwiński, R. Podemski, 2008, Prozodia mowy w niedokrwiennym udarze mózgu, „Udar Mózgu” 10(2), s. 96-103.

K.M. Heilman, D. Bowers, L. Speedie, H.B. Coslett, 1984, Comprehension of affective and nonaffective prosody, „Neurology” 34, s. 917-921. 
K. Jodzio, 2001, Zaburzenia czytania i pisania u osób z uszkodzeniem prawej półkuli mózgu, „Przegląd Psychologiczny” z. 44, nr 4, s. 509-525.

K. Kucharska-Pietura, M. Klimkowski, 2002, Kliniczne aspekty emocji w zdrowym i chorym mózgu, Kraków.

K. Kucharska-Pietura, M. Klimkowski, 2002a, Perception of facial affect in chronic schizophrenia and right brain damage, „Acta Neurobiologiae Experimentalis" 62(1), s. 33-43.

T. Lewicka, M. Patalong-Ogiewa, 2013, Pacjent z uszkodzeniem prawej pótkuli w pracy logopedy, „Logopedia Silesiana” 2, s. 73-83.

E. Łojek, 2007, Podręcznik do Baterii Testów do Oceny Funkcji Językowych i Komunikacyjnych Prawej Półkuli Mózgu (RHLB-PL), Warszawa.

G. Monrad-Krohn, 1947, Dysprosody or altered "melody of language”, „Brain” 70, s. 405-415.

E. Osiejuk, 1994, Procesy komunikacji językowej u osób z uszkodzona prawa półkula mózgu [w:] H. Marczewska, E. Osiejuk (red.), Nie tylko afazja... O zaburzeniach językowych $w$ demencji Alzheimera, demencji wielozawałowej i przy uszkodzeniach prawej półkuli mózgu, Warszawa, s. 61-86.

J. Panasiuk, 2008, Standard postępowania logopedycznego w pragnozji, „Logopedia" 37, s. 279-296.

J. Panasiuk, 2015, Postepowanie logopedyczne $w$ przypadku pragnozji [w:] S. Grabias, J. Panasiuk, T. Woźniak (red.), Logopedia. Standardy postępowania, Lublin, s. 721-753.

M. Pąchalska, B.D. MacQueen, 2002, Rozpad pragmatyki u chorych z uszkodzeniem prawej pótkuli mózgu [w:] A. Herzyk, B. Daniluk (red.), Jakościowy opis $w$ neuropsychologii, Lublin, s. 41-72.

M.D. Pell, S.R. Baum, 1997, Unilateral brain damage, prosodic comprehension deficits, and the acoustic cues to prosody, "Brain and Language” 57, s. 195-214.

E.D. Ross, 1981, The aprosodias. Functional-Anatomic organization of the affective components of language in the right hemisphere, "Archives of Neurology” 38, s. 561-569.

A. Rożek, D. Larysz, 2014, Zaburzenia czynności językowych w przypadku uszkodzeń prawopółkulowych na przykładzie pacjentów po udarach niedokrwiennych, „Logopedia Silesiana” 3, s. 182-191.

K. Rymarczyk, 1999, Zaburzenia prozodii emocjonalnej i lingwistycznej u pacjentów z uszkodzeniami mózgu, „Przegląd Psychologiczny” 42(1-2), s. 135-150.

M. Senderecka, 2007, Różne punkty widzenia prawej i lewej półkuli mózgu, "Przegląd Psychologiczny” 50(2), s. 149-164.

C.A. Tompkins, 1995, Right hemisphere communication disorders: theory and management, San Diego.

D.A. Trauner, A. Bellantyne Friendland, C. Chase, 1996, Disorders of affective and linguistic prosody in children after early unilateral brain damage „Annual of Neurology" 39, s. 361-367.

K. Walsh, 2008, Neuropsychologia kliniczna, Warszawa.

E. Winner, H. Gardner, 1977, The comprehension of metaphor in brain damaged patients, „Brain” 100, s. 717-723.

M. Wysocka, 2012, Prozodia mowy $w$ percepcji dzieci, Lublin.

J. Żulewska, 2012, Prawa pótkula mózgu a język - przegląd badań, „Poradnik Językowy" z. 10, s. 77-92. 


\section{Disorders of language and communication skills of people with right hemisphere brain damage. Case reports}

\section{Summary}

Right hemisphere brain damage manifests itself in the language at the level of not only expression but also reception. Utterances of people with right hemisphere dysfunctions are often disorderly and illogical. As recipients, patients with right hemisphere brain damage, for instance, interrupt their interlocutor's utterance, cannot understand jokes, mockeries, or ambiguous messages.

The paper describes language and communication deficits arising from right hemisphere brain damage and cases of patients suffering from right hemisphere disorder. The data obtained in the course of examining people with right hemisphere damage show that the most disturbed aspects of language include: lexical and semantic processing, processing complex language information, discourse, and prosody.

Keywords: language deficits - communication disorders - pragnosia - right hemisphere brain damage - emotional disorders.

Trans. Monika Czarnecka 